\title{
POSITIONING OF PEDICLE SCREWS IN ADOLESCENT IDIOPATHIC SCOLIOSIS USING ELECTROMYOGRAPHY
}

\author{
POSIÇÃO DE PARAFUSOS PEDICULARES NA ESCOLIOSE IDIOPÁTICA DO ADOLESCENTE \\ COM USO DA ELETROMIOGRAFIA
}

\author{
POSICIÓN DE TORNILLOS PEDICULARES EN ESCOLIOSIS IDIOPÁTICA DEL \\ ADOLESCENTE CON ELECTROMIOGRAFIA
}

Bruno Moreira Gavassi', Raphael de Rezende Pratali', Carlos Eduardo Gonçales Barsotti', Ricardo José Rodriguez Ferreira', Francisco Prado Eugenio dos Santos ${ }^{1}$, Carlos Eduardo Algaves Soares de Oliveira ${ }^{1}$

\begin{abstract}
Objective: To analyze the occurrence of poor positioning of pedicle screws inserted with the aid of intraoperative electromyographic stimulation in the treatment of Adolescent Idiopathic Scoliosis (AIS). Methods: This is a prospective observational study including all patients undergoing surgical treatment for AIS, between March and December 2013 at a single institution. All procedures were monitored by electromyography of the inserted pedicle screws. The position of the screws was evaluated by assessment of postoperative CT and classified according to the specific AIS classification system. Results: Sixteen patients were included in the study, totalizing 281 instrumented pedicles (17.5 per patient). No patient had any neurological deficit or complaint after surgery. In the axial plane, 195 screws were found in ideal position (69.4\%) while in the sagittal plane, 226 screws were found in ideal position (80.4\%). Considering both the axial and the sagittal planes, it was observed that $59.1 \%(166 / 281)$ of the screws did not violate any cortical wall. Conclusion: The use of pedicle screws proved to be a safe technique without causing neurological damage in AIS surgeries, even with the occurrence of poor positioning of some implants.
\end{abstract}

Keywords: Scoliosis; Bone screw; Intraoperative neurophysiological monitoring; Tomography, X-ray computed.

\section{RESUMO}

Objetivo: Analisar a ocorrência do mau posicionamento de parafusos pediculares inseridos com auxílio de estimulação eletromiográfica intraoperatória, no tratamento de escoliose idiopática do adolescente (EIA). Métodos: Trata-se de um estudo observacional e prospectivo, incluindo todos os pacientes submetidos a tratamento cirúrgico para EIA, entre março e dezembro de 2013, em uma única instituição. Todos os procedimentos foram monitorados por eletromiografia (EMG) dos parafusos pediculares inseridos. A posição dos parafusos foi avaliada por exame de tomografia computadorizada (TC) pós-operatória e classificada de acordo com sistema de classificação próprio para ElA. Resultados: Dezesseis pacientes foram incluídos no estudo, num total de 281 pedículos instrumentados (17,5 por paciente). Nenhum paciente apresentou qualquer déficit ou queixa neurológica após a cirurgia. No plano axial, 195 parafusos estavam em posição ideal (69,4\%) enquanto no plano sagital, 226 parafusos estavam em posição ideal (80,4\%). Considerando tanto o plano axial quanto o sagital, foi observado que 59,1\% (166/281) dos parafusos não violaram nenhuma parede cortical. Conclusão: O uso de parafusos pediculares mostrou-se uma técnica segura, sem causar danos neurológicos em cirurgias para EIA, mesmo com a ocorrência de mau posicionamento de alguns implantes.

Descritores: Escoliose; Parafusos ósseos; Monitorização neurofisiológica intraoperatória; Tomografia computadorizada por raios X.

\section{RESUMEN}

Objetivo: Analizar la incidencia de la mala colocación de tornillos pediculares insertados con la ayuda de la estimulación electromiográfica intraoperatoria para el tratamiento de la Escoliosis Idiopática del Adolescente (EIA). Métodos: Se realizó un estudio observacional prospectivo de todos los pacientes sometidos a tratamiento quirúrgico para la ElA, entre marzo y diciembre de 2013 en una sola institución. Todos los procedimientos fueron monitoreados por electromiografía (EMG) de los tornillos pediculares insertados. La posición de los tornillos se evaluó mediante análisis de la TC postoperatoria y fue clasificada por la clasificación especifica para EIA. Resultados: Dieciséis pacientes fueron incluidos en el estudio, con un total de 281 pedículos instrumentados (17,5 por paciente). Ningún paciente ha tenido ningún déficit o queja neurológicos después de la cirugía. En el plano axial, 195 tornillos estaban en la posición ideal (69,4\%), mientras que en el plano sagital, 226 tornillos estaban en la posición ideal (80,4\%). Teniendo en cuenta tanto el plano axial como el sagital, se observó que el 59,1\% (166/281) de los tonillos no violó ninguna de las paredes corticales. Conclusión: El uso de tornillos pediculares ha demostrado ser una técnica segura sin causar daño neurológico en cirugías de la EIA, incluso con la ocurrencia de la mala posición de algunos implantes.

Descriptores: Escoliosis; Tornillos óseos; Monitorización neurofisiológica intraoperatoria; Tomografía computarizada por rayos X.

\section{INTRODUCTION}

The use of the pedicle screw is becoming increasingly frequent for rigid fixation in spine fusion, and is especially common in the surgical treatment of adolescent idiopathic scoliosis (AIS). Initially described for lumbar segments of the spine, ${ }^{1,2}$ its safety at thoracic levels has also been demonstrated by various authors. ${ }^{3-7}$ Segmental instrumentation with pedicle screws enables better correction of deformities in the coronal, sagittal and rotational planes, less loss of

1. Hospital do Servidor Público Estadual de São Paulo, Spinal Surgery Group of the Orthopedics and Traumatology Service, São Paulo, SP, Brazil.

Study conducted at Hospital do Servidor Publico Estadual (HSPE), São Paulo, SP, Brazil.

Correspondence: Rua Borges Lagoa, 1755, Sala 180, Vila Clementino, São Paulo, SP, Brazil. 04038-034. pratalir@gmail.com 
reduction, shorter constructions, and improvement in lung function, without any increase in neurological complications, when compared with instrumentation with hooks, or hybrid instrumentation (proximal hooks and distal pedicle screws). ${ }^{8,9}$

Due to the unique anatomical, vascular and neurological characteristics around the vertebral canal, care is needed when inserting the pedicle screws, ensuring precise insertion and confirming the intraosseous position of the screws, with the aim of improving the safety of the procedure..$^{10}$ Intraoperative neurophysiology (ION) during placement of the screws is currently a primary care that enables early detection and reversal of many neurological complications. ${ }^{11-13}$ For this technique, motor evoked potential (MEP), somatosensory evoked potential (SSEP), free-running electromyography (EMG-FR) and stimulated electromyography (EMG-ST) are used, the latter being performed directly on the inserted implants. ${ }^{14,15}$

In patients with scoliosis, due to the rotational deformity, the risk of violation of the medial cortical or lateral wall of the pedicle is even greater, but is not always easy to spot during the surgical procedure. Intraoperative evaluation of the position of the screws with conventional fluoroscopy or radiography will assist in the detection of poorly positioned implants, although the accuracy obtained with computed tomography (CT) will be greater for this determination. ${ }^{16}$ In this aspect, EMG-ST provides additional information, establishing a link between the implants and the neural elements.

The objective of this study was to analyze the position of pedicle screws implanted during surgical treatment of AlE with the aid of intraoperative EMG-ST, with postoperative computed tomography exam.

\section{METHODS}

This is a prospective study in patients submitted to surgery by the posterior approach for correction of adult idiopathic scoliosis. After approval of the study by the Institutional Review Board (IRB) of the service responsible for the study (opinion number 533.892), patients were included after they, or their guardians, had signed the Informed Consent Form (ICF) and who had undergone a postoperative CT scan of the vertebral spine. Those with secondary scoliosis by another cause were excluded, as were patients submitted to revision surgery, and those who had not undergone a postoperative CT scan.

All the surgical procedures were performed at the same service, and by the same team, between March and December 2013. In all the surgeries, the instrumentation was exclusively by pedicle screws (all the implants were from the same supplier), inserted using the Free Hands technique. ${ }^{10}$

All the surgeries were performed under ION monitoring, by the same team, using the same technique and the same equipment. The anesthesia used was totally intravenous, in order to interfere as little as possible in the responses of the neurophysiological tests. ${ }^{17}$ After placement of the screws in their respective pedicles, the EMGST stage was performed directly on the implants. (Figure 1) For this stimulus, a monopolar electrode (cathode) and a straight subdermal needle injected inserted into the paravertebral musculature (anode) were used. The technical stimulation parameters that we used were: frequency of $3 \mathrm{~Hz}$, duration of $0.1 \mathrm{~ms}$, with stimulation intensity (milliamperes) increased to provoke the emergence of a response in the EMG. ${ }^{14,15,18}$ The maximum stimulation value used was 30 milliamperes $(\mathrm{mA})$.

After surgery, the patients underwent a computed tomography exam. The positioning of the screws was evaluated and classified according to the classification proposed by Abul-Kasim et al. ${ }^{19}$ which considers and grades the medial cortical perforation (MCP), lateral cortical perforation (LCP), and foraminal perforation (FP). (Figure 2)

\section{RESULTS}

The study included 16 patients: 12 female (75\%) and four male (25\%), with ages ranging from 11 to 26 years (average of 16.6 years). In all, 281 pedicles were instrumented (average of 17.5 per patient) with a minimum of 12 and a maximum of 26 . The minimum follow-up

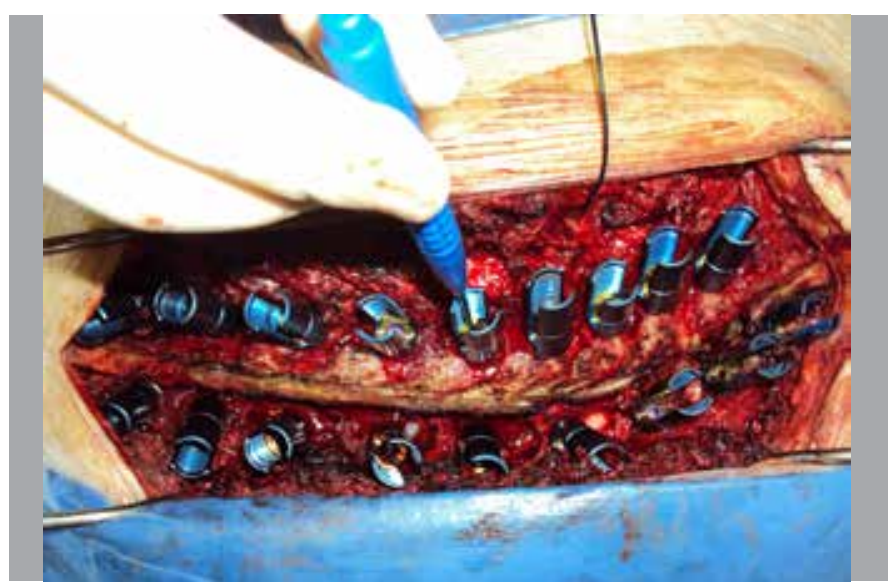

Figure 1. Electromyography stimulated through the electrode positioned directly in the screw implanted in the pedicles.

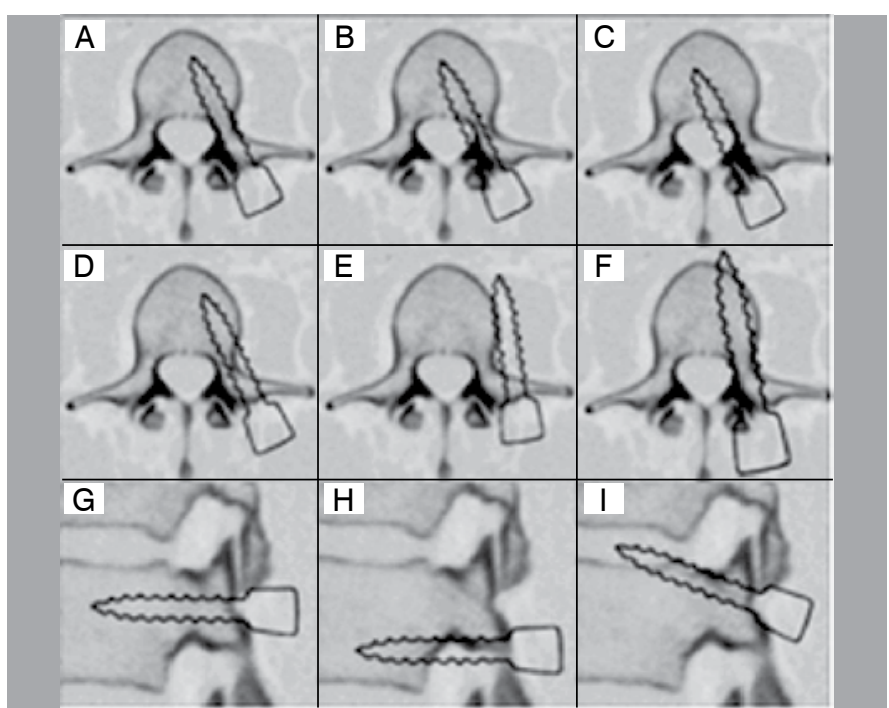

Figure 2. Classification of the position of the pedicle screws proposed by Abul-Kasim et al.19 The position is classified in the axial planes (A: LCP/MCP0; B: MCP1; C: MCP2; D: LCP1; E: LCP2; F: Anterior Cortical) and sagittal (G: FPO, H: FPI, I: FPS).

time after surgery was 3 months; no patient presented any neurological complaint or alteration in the physical exam; and there was no complaint of irradiated pain in dermatomal region that would lead to a suspicion of radicular compression or lesion.

According to Table 1, in relation to the axial plane of the pedicle, 195 screws were in the ideal position (69.4\%). 41 screws violated the lateral cortical bone, of which 25 (8.9\%) were classified as LCP1 and $16(5.7 \%)$ as LCP2. 45 violated the medial cortical bone, of which 27 (9.6\%) were classified as MCP1, and 18 (6.4\%) as MCP2. As illustrated in Table 2, in relation to the sagittal plane, 226 screws $(80.4 \%)$ were in the ideal position, of which $48(17.1 \%)$ violated the inferior foramen (FP1 INF) and 7 (2.5\%) violated the superior foramen (FP1 SUP). Considering both the axial and sagittal planes, it was observed that $59.1 \%(166 / 281)$ of the screws did not violate any cortical bone (lateral, medial and upper and lower foramens), while 40.9\% (115/281) presented at least a minimal degree of cortical violation in some or more than one plane. (Table 3)

\section{DISCUSSION}

The use of pedicle fixation systems in the surgical treatment of thoracolumbar spine has become increasingly common. Biomechanical studies demonstrate the superiority of pedicle fixation, in terms of the fusion rate, power of correction and early mobilization, over 
Table 1. Description of the positions of the screws in the axial plan for each patient, and in the total pedicles evaluated.

\begin{tabular}{|c|c|c|c|c|c|c|c|c|c|c|c|}
\hline \multirow[b]{2}{*}{ Patient } & \multicolumn{10}{|c|}{ Axial plane } & \multirow[b]{2}{*}{ Total } \\
\hline & \multicolumn{2}{|c|}{ LCP 2} & \multicolumn{2}{|c|}{ LCP 1} & \multicolumn{2}{|c|}{ LCP 0/MCP 0} & \multicolumn{2}{|c|}{ MCP 1} & \multicolumn{2}{|c|}{ MCP 2} & \\
\hline 1 & 4 & 15.4 & 0 & 0.0 & 17 & 65.4 & 3 & 11.5 & 2 & 7.7 & 26 \\
\hline 3 & 1 & 6.7 & 1 & 6.7 & 13 & 86.7 & 0 & 0.0 & 0 & 0.0 & 15 \\
\hline 4 & 0 & 0.0 & 1 & 6.2 & 9 & 56.2 & 3 & 18.8 & 3 & 18.8 & 16 \\
\hline 5 & 0 & 0.0 & 2 & 9.1 & 15 & 68.2 & 3 & 13.6 & 2 & 9.1 & 22 \\
\hline 7 & 1 & 6.2 & 2 & 12.5 & 10 & 62.5 & 1 & 6.2 & 2 & 12.5 & 16 \\
\hline 8 & 1 & 5.0 & 3 & 15.0 & 13 & 65.0 & 1 & 5.0 & 2 & 10.0 & 20 \\
\hline 9 & 1 & 8.3 & 2 & 16.7 & 8 & 66.7 & 1 & 8.3 & 0 & 0.0 & 12 \\
\hline 10 & 2 & 11.1 & 1 & 5.6 & 12 & 66.7 & 2 & 11.1 & 1 & 5.6 & 18 \\
\hline 11 & 1 & 5.6 & 3 & 16.7 & 12 & 66.7 & 1 & 5.6 & 1 & 5.6 & 18 \\
\hline 12 & 2 & 11.1 & 2 & 11.1 & 11 & 61.1 & 2 & 11.1 & 1 & 5.6 & 18 \\
\hline 16 & 0 & 0.0 & 0 & 0.0 & 12 & 100.0 & 0 & 0.0 & 0 & 0.0 & 12 \\
\hline Total & 16 & 5.7 & 25 & 8.9 & 195 & 69.4 & 27 & 9.6 & 18 & 6.4 & 281 \\
\hline
\end{tabular}

Table 2. Description of the positions of the screws in the sagittal plane for each patient, and in the total pedicles evaluated.

\begin{tabular}{c|c|c|c|c|c|c|c}
\hline & \multicolumn{7}{|c|}{ Sagittal plane } \\
\hline Patient & \multicolumn{2}{|c|}{ FP 1 (inf.) } & \multicolumn{2}{|c|}{ FP 0 } & \multicolumn{2}{c|}{ FP 1 (sup.) } & Total \\
\hline & $\mathrm{n}$ & $\%$ & $\mathrm{n}$ & $\%$ & $\mathrm{n}$ & $\%$ & \\
\hline 1 & 0 & 0.0 & 26 & 100.0 & 0 & 0.0 & 26 \\
\hline 2 & 1 & 5.3 & 17 & 89.5 & 1 & 5.3 & 19 \\
\hline 3 & 4 & 26.7 & 11 & 73.3 & 0 & 0.0 & 15 \\
\hline 4 & 6 & 37.5 & 10 & 62.5 & 0 & 0.0 & 16 \\
\hline 5 & 1 & 4.5 & 18 & 81.8 & 3 & 13.6 & 22 \\
\hline 6 & 9 & 50.0 & 9 & 50.0 & 0 & 0.0 & 18 \\
\hline 7 & 4 & 25.0 & 12 & 75.0 & 0 & 0.0 & 16 \\
\hline 8 & 0 & 0.0 & 18 & 90.0 & 2 & 10.0 & 20 \\
\hline 9 & 0 & 0.0 & 12 & 100.0 & 0 & 0.0 & 12 \\
\hline 10 & 5 & 27.8 & 13 & 72.2 & 0 & 0.0 & 18 \\
\hline 11 & 8 & 44.4 & 10 & 55.6 & 0 & 0.0 & 18 \\
\hline 12 & 6 & 33.3 & 12 & 66.7 & 0 & 0.0 & 18 \\
\hline 13 & 2 & 10.5 & 17 & 89.5 & 0 & 0.0 & 19 \\
\hline 14 & 0 & 0.0 & 18 & 100.0 & 0 & 0.0 & 18 \\
\hline 15 & 1 & 7.1 & 13 & 92.9 & 0 & 0.0 & 14 \\
\hline 16 & 1 & 8.3 & 10 & 83.3 & 1 & 8.3 & 12 \\
\hline Total & 48 & 17.1 & 226 & 80.4 & 7 & 2.5 & 281 \\
\hline & & & & & & & \\
\hline
\end{tabular}

Table 3. Description of the screws in the ideal position in the sagittal and axial planes (FPO and LCP/MCPO) and in inadequate position in some of the planes (FP $\neq 0$ or $L C P / M C P \neq 0$ ).

\begin{tabular}{c|c|c|c|c|c}
\hline \multirow{2}{*}{ Patient } & \multicolumn{2}{|c|}{ FP 0 and LCP 0/MCP 0 } & \multicolumn{2}{c|}{ FP or LCP/MCP $\neq \mathbf{0}$} & \multirow{2}{*}{ Total } \\
\cline { 2 - 5 } & $\mathbf{n}$ & $\mathbf{\%}$ & $\mathbf{n}$ & $\mathbf{0}$ & \\
\hline 1 & 17 & 65.4 & 9 & 34.6 & 26 \\
\hline 2 & 13 & 68.4 & 6 & 31.6 & 19 \\
\hline 3 & 10 & 66.7 & 5 & 33.3 & 15 \\
\hline 4 & 7 & 43.8 & 9 & 56.2 & 16 \\
\hline 5 & 14 & 63.6 & 8 & 36.4 & 22 \\
\hline 6 & 6 & 33.3 & 12 & 66.7 & 18 \\
\hline 7 & 6 & 37.5 & 10 & 62.5 & 16 \\
\hline 8 & 13 & 65.0 & 7 & 35.0 & 20 \\
\hline 9 & 8 & 66.7 & 4 & 33.3 & 12 \\
\hline 10 & 9 & 50.0 & 9 & 50.0 & 18 \\
\hline 11 & 8 & 44.4 & 10 & 55.6 & 18 \\
\hline 12 & 8 & 44.4 & 10 & 55.6 & 18 \\
\hline 13 & 13 & 68.4 & 6 & 31.6 & 19 \\
\hline 14 & 12 & 66.7 & 6 & 33.3 & 18 \\
\hline 15 & 12 & 85.7 & 2 & 14.3 & 14 \\
\hline 16 & 10 & 83.3 & 2 & 16.7 & 12 \\
\hline Total & 166 & 59.1 & 115 & 40.9 & 281 \\
\hline
\end{tabular}

fixation systems by hooks, or mixed systems. ${ }^{20,21}$ The neurological complications reported in the literature, resulting from inadequate positioning of the pedicle screws, range from $0 \%$ to $0.9 \% .{ }^{22,23}$ In the present study, no complications were observed during the entire patient follow-up.

Intraoperative neurophysiology is currently a primary care that enables early detection and reversion of possible complications during surgical treatment of the spine, including the techniques of MEP, SSEP and EMG-ST. ${ }^{11-13}$ The persistently electrified pedicle stimulation instrument technique, EMG-ST, enables monitoring and identification of perforations of the pedicle wall, before a lesion of the neural root occurs. ${ }^{11,24}$ Obtaining responses to EMG-ST with thresholds lower than 4 or $5 \mathrm{~mA}$ is strongly suggestive of perforation of the cortical bone by transpedicular instrumentation, while a response with thresholds higher than $15 \mathrm{~mA}$ is indicative of adequate positioning. ${ }^{25}$

In relation to pedicle instrumentation by the Freehand technique, there is a fear of neurological damage, especially when the cortical wall of the medial pedicle is violated. ${ }^{10}$ However, small violations are common, and are generally asymptomatic. Numerous publications demonstrate that violations $\leq 2 \mathrm{~mm}$ are harmless, ${ }^{7,10,21}$ hence the term "questionable safe zone" is attributed to violations between 4 and $8 \mathrm{~mm} .^{10}$

The occurrence of poorly positioned screws in the pedicle varies between $3 \%$ and $44 \% .{ }^{22}$ In Brazil, De Marco et al. ${ }^{26}$ studied the position of pedicle screws inserted without the use of EMG in 24 patients, but 183 pedicles - that study did not determine a specific pathology as in our study, with all the patents having $\mathrm{AIE}$ - and observed that $36.06 \%$ of the screws present a lesion of the cortical wall of the pedicle. In our study, even with the aid of ECG, misplaced positioning was observed, with at least one pedicle cortical wall being violated, in $40.9 \%$ of the screws. However, we considered only patients submitted to surgery for correction of AIS, in the presence of vertebrae with rotational and structural deformity.

In the present study, there was perforation of the lateral cortical wall of the pedicle in $14.6 \%$ of the screws. These values agree with

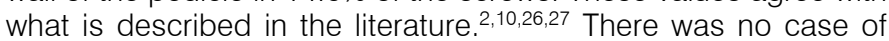
vascular, neurological or visceral damage. In relation to the medial cortical wall of the pedicles, values of between $1.4 \%$ and $14 \%$ of inadequate positioning are described, 2,10,26,27 reaching up to $28 \%$ according to Farber et al. ${ }^{28}$ In the present study, there was perforation of the medical cortical in $16 \%$ of the screws. 
Due to the position of the nerve root in the upper third of the intervertebral foramen, immediately below the lower cortical of the pedicle, inadequate positioning of the screws, perforating the lower foramen, can result in radicular signs and symptoms more frequently when there is inadequate positioning, violating the foramen superiorly, where there is fat surrounding the nerve root that isolates it in the violated pedicle. In the present study, $17.1 \%$ of the screws perforated the lower cortical and $2.5 \%$ perforated the upper cortical of the pedicle. No patient in the sample presented any radicular sign or symptom.

\section{CONCLUSION}

The use of pedicle screws by the Free Hands technique, with the aid of intraoperative EMG-ST, proved to be a safe technique in the surgical treatment of AIS, without any case of neural or visceral damage, even with the occurrence of misplaced positioning of some of the implants in the pedicle.

All authors declare no potential conflict of interest concerning this article.

\section{REFERENCES}

1. Brown CA, Lenke LG, Bridwell KH, Geideman WM, Hasan SA, Blanke K. Complications of pediatric thoracolumbar and lumbar pedicle screws. Spine (Phila Pa 1976). 1998;23(14):1566-71.

2. Hamill CL, Lenke LG, Bridwell KH, Chapman MP, Blanke K, Baldus C. The use of pedicle screw fixation to improve correction in the lumbar spine of patients with idiopathic scoliosis. Is it warranted? Spine (Phila Pa 1976). 1996;21(10):1241-9.

3. Suk SI, Lee CK, Kim WJ, Chung YJ, Park YB. Segmental pedicle screw fixation in the treatment of thoracic idiopathic scoliosis. Spine (Phila Pa 1976). 1995:20(12):1399-405.

4. Liljenqvist UR, Halm HF, Link TM. Pedicle screw instrumentation of the thoracic spine in idiopathic scoliosis. Spine (Phila Pa 1976). 1997;22(19):2239-45.

5. Halm H, Niemeyer T, Link T, Liljenqvist U. Segmental pedicle screw instrumentation in idiopathic thoracolumbar and lumbar scoliosis. Eur Spine J. 2000;9(3):191-7.

6. Suk SI, Kim WJ, Lee SM, Kim JH, Chung ER. Thoracic pedicle screw fixation in spinal deformities: are they really safe? Spine (Phila Pa 1976). 2001;26(18):2049-57.

7. Belmont PJ Jr, Klemme WR, Dhawan A, Polly DW Jr. In vivo accuracy of thoracic pedicle screws. Spine (Phila Pa 1976). 2001;26(21):2340-6.

8. Kim YJ, Lenke LG, Cho SK, Bridwell KH, Sides B, Blanke K. Comparative analysis of pedicle screw versus hook instrumentation in posterior spinal fusion of adolescent idiopathic scoliosis. Spine (Phila Pa 1976). 2004;29(18):2040-8.

9. Kim YJ, Lenke LG, Kim J, Bridwell KH, Cho SK, Cheh G, et al. Comparative analysis of pedicle screw versus hybrid instrumentation in posterior spinal fusion of adolescent idiopathic scoliosis. Spine (Phila Pa 1976). 2006:31(3):291-8.

10. Kim YJ, Lenke LG, Bridwell KH, Cho YS, Riew KD. Free hand pedicle screw placement in the thoracic spine: is it safe? Spine (Phila Pa 1976). 2004;29(3):333-42.

11. Holland NR. Intraoperative electromyography during thoracolumbar spinal surgery. Spine (Phila Pa 1976). 1998;23(17):1915-22.

12. Nuwer MR, Dawson EG, Carlson LG, Kanim LEA, Sherman JE. Somatosensory evoked potential spinal cord monitoring reduces neurological deficits after scoliosis surgery: results of a large multicenter survey. Electroencephalogr Clin Neurophysiol. 1995;96(1):6-11.

13. Accadbled F, Henry P, de Gauzy JS, Cahuzac JP. Spinal cord monitoring in scoliosis surgery using an epidural electrode. Results of a prospective, consecutive series of 191 cases. Spine (Phila Pa 1976). 2006:31(22):2614-23.

14. Cavali PTM. Transpedicular stabilization with free hand technique on the toracic spine. In: Vieweg U, Grochulla F. Manual of spine surgery. New York: Springer-Verlag; 2012. p. 235-41.

15. Ferreira RJR. Neurofisiologia intraoperatória. In: Pudles E, Defino HL. Coluna vertebral: conceitos básicos. São Paulo: Artmed; 2014. p. 85-94.

16. Kim YJ, Lenke LG, Cheh G, Riew KD. Evaluation of pedicle screw placement in the de- formed spine using intraoperative plain radiographs: a comparison with computerized tomography. Spine (Phila Pa 1976). 2005;30(18):2084-8.

17. Taniguchi M, Nadstawek J, Pechstein U, Schramm J. Total intravenous anesthesia for improvement of intraoperative monitoring of somatosensory evoked potentials during aneurysm surgery. Neurosurgery. 1992:31(5):891-7.

18. Ferreira RJR. Monitoramento neurofisiológico intraoperatório nas cirurgias espinais. In: Chamlian TR. Medicina de reabilitação. Rio de Janeiro: Guanabara; 2010. p. 24-41.

19. Abul-Kasim K, Strömbeck A, Ohlin A, Maly P, Sundgren PC. Reliability of low-radiation dose $\mathrm{CT}$ in the assessment of screw placement after posterior scoliosis surgery, evaluated with a new grading system. Spine (Phila Pa 1976). 2009;34(9):941-8.

20. Bess RS, Lenke LG, Bridwell KH, Cheh G, Mandel S, Sides B. Comparison of thoracic pedicle screw to hook instrumentation for the treatment of adult spinal deformity. Spine (Phila Pa 1976). 2007;32(5):555-61.

21. Liljenqvist $U$, Lepsien $U$, Hackenberg $L$, Niemeyer $T$, Halm $H$. Comparative analysis of pedicle screw and hook instrumentation in posterior correction and fusion of idiopathic thoracic scoliosis. Eur Spine J. 2002;11(4):336-43

22. Schwarzenbach O, Berlemann U, Jost B, Visarius $H$, Arm E, Langlotz F, et al. Accuracy of computer-assisted pedicle screw placement. An in vivo computed tomography analysis. Spine (Phila Pa 1976). 1997;22(4):452-8

23. Esses SI, Sachs BL, Dreyzin V. Complications associated with the technique of pedicle screw fixation. A selected survey of ABS members. Spine (Phila Pa 1976). 1993:18(15):2231-8

24. Rose RD, Welch WC, Balzer JR, Jacobs GB. Persistently electrified pedicle stimulation instruments in spinal instrumentation. Technique and protocol development. Spine (Phila Pa 1976). 1997;22(3):334-43.

25. Glassman SD, Dimar JR, Puno RM, Johnson JR, Shields CB, Linden RD. A prospective analysis of intraoperative electromyographic monitoring of pedicle screw placement with computed tomographic scan confirmation. Spine (Phila Pa 1976). 1995:20(12):1375-9.

26. De Marco FA, Risso Neto MI, Cavali PTM, Sussi MA, Pasqualini W, Landim E, et al. Avaliação do posicionamento de parafusos pediculares na coluna torácica e lombar introduzidos com base em referenciais anatômicos e radioscópicos. Coluna/Columna. 2008;7(1):1-7.

27. Amiot LP, Lang K, Putzier M, Zippel H, Labelle H. Comparative results between conventional and computer-assisted pedicle screw installation in the thoracic, lumbar, and sacral spine. Spine (Phila Pa 1976). 2000;25(5):606-14

28. Farber GL, Place HM, Mazur RA, Jones DE, Damiano TR. Accuracy of pedicle screw placement in lumbar fusions by plain radiographs and computed tomography. Spine (Phila Pa 1976). 1995;20(13):1494-9. 